\title{
Penaeus monodon is protected against gill- associated virus by muscle injection but not oral delivery of bacterially expressed dsRNAs
}

\author{
Melony J. Sellars ${ }^{1, *}$, Min Rao ${ }^{2}$, Stuart J. Arnold ${ }^{1}$, Nicholas M. Wade ${ }^{1}$, \\ Jeff A. Cowley ${ }^{2}$ \\ ${ }^{1}$ CSIRO Food Futures National Research Flagship, CSIRO Marine and Atmospheric Research, Cleveland, Queensland 4163, \\ Australia \\ ${ }^{2}$ CSIRO Food Futures National Research Flagship, CSIRO Livestock Industries, Queensland Bioscience Precinct, St Lucia, \\ Queensland 4067, Australia
}

\begin{abstract}
Gill-associated virus (GAV) is a nidovirus that commonly infects Penaeus monodon (black tiger shrimp) in eastern Australia, causing morbidity and mortalities in the acute stage of disease. Here we explored the possibility of inhibiting GAV replication and disease using doublestranded (ds)RNAs expressed in bacteria and delivered either orally or by muscle injection. To enhance potential RNA interference (RNAi) responses, 5 long dsRNAs were used that targeted open reading frame $1 \mathrm{a} / 1 \mathrm{~b}(\mathrm{ORF} 1 \mathrm{a} / \mathrm{b})$ gene regions and thus only the genomic length RNA. To examine oral delivery, $P$. monodon were fed pellets incorporating a pool of formalin-fixed bacteria containing the 5 GAV-specific dsRNAs before being injected with a minimal lethal GAV dose. Feeding with the pellets continued post-challenge but did not reduce mortality accumulation and elevation in GAV loads. In contrast, muscle injection of the dsRNAs purified from bacteria was highly effective at slowing GAV replication and protecting shrimp against acute disease and mortalities. In synergy with these data, dsRNA targeted to $P$. monodon $\beta$-actin mRNA caused $100 \%$ mortality following injection, whilst its oral delivery caused no mortality. Findings confirm that injected dsRNA can mount effective RNAi responses in P. monodon to endogenous shrimp mRNA and exogenous viral RNAs, but when delivered orally in bacteria as a feed component, the same dsRNAs are ineffective. The efficacy of the RNAi response against GAV provided by injection of dsRNAs targeted to multiple genome sites suggests that this strategy might have general applicability in enhancing protection against other shrimp single-stranded (ss)RNA viruses, particularly in hatcheries or breeding programs where injection-based delivery systems are practical.
\end{abstract}

KEY WORDS: Actin · Gill-associated virus $\cdot$ GAV $\cdot$ RNA interference $\cdot$ RNAi $\cdot$ Giant tiger shrimp

\section{INTRODUCTION}

It has recently been discovered that penaeid shrimp possess the intracellular machinery needed to mount a gene-specific RNA interference (RNAi) response to double-stranded (ds)RNAs, including a Dicer-1 type ribonuclease (Su et al. 2008) and an Argonaute-like protein (Unajak et al. 2006, Dechklar et al. 2008). The existence of this RNAi machinery is thus being exploited widely to determine gene functions in shrimp. Due to its ability to specifically target and degrade endogenous mRNAs, the RNAi response is being investigated as a means of down-regulating the expression of genes that might, for example, promote spawning (Lugo et al. 2006, Tiu and Chan 2007, Treerattrakool et al. 2008), direct traits such as gender (Sellars 2007, Tiu et al. 2008) and modulate the rate of haemolymph clotting (Maningas et al. 2008). As in many other organisms, the RNAi response mechanism of shrimp is also capturing research attention as a means of interfering with the 
replication of viruses and other pathogens to protect the shrimp against several serious diseases of economic importance to aquaculture.

The injection of various shrimp species with dsRNAs or hairpin dsRNAs targeting viral RNAs has been shown to interfere with virus replication and provide at least short-term protection against disease and mortalities caused by white spot syndrome virus (WSSV) (Robalino et al. 2004, 2005, 2007, Westenberg et al. 2005, Xu et al. 2007), Taura syndrome virus (TSV) (Robalino et al. 2004, 2005, 2007) and yellow head virus (YHV) (Tirasophon et al. 2005, Assavalapsakul et al. 2006, Yodmuang et al. 2006,). Moreover, antiviral effects have been produced in shrimp injected with short-interfering (si) dsRNAs (Robalino et al. 2005, Westenberg et al. 2005). However, the shrimp RNAi response generated by such siRNAs does not appear to provide the specificity or efficacy of long dsRNAs.

Whilst experimental evidence that dsRNA can protect shrimp against viral disease promises much, little has been published on effective means by which RNAi-based protection might be delivered to farmed shrimp on commercial scales. In this context, the delivery of therapeutic dsRNAs orally as a feed component is attractive due to its convenience, amenability to existing commercial scale feed production systems and the regularity of delivery likely to be needed to sustain protection throughout shrimp grow-out. Recently, such an oral delivery approach has been trialled using feed pellets coated with bacteria in which dsRNA targeted to the VP28 gene of WSSV had been expressed (Sarathi et al. 2008). In Penaeus monodon (black tiger shrimp) fed this feed and challenged by feeding on meat of shrimp infected with WSSV, mortality onset was delayed, some shrimp were protected at least in the short term, and VP28 mRNA and protein levels were observed to be diminished in the protected shrimp.

To further investigate the possibility of delivering dsRNA orally to shrimp via feed, similar experiments were undertaken here using either dsRNA targeted to a $\beta$-actin mRNA sequence of Penaeus monodon or to a suite of 5 dsRNAs targeted to various open reading frame $(\mathrm{ORF} 1 \mathrm{a} / \mathrm{b})$ gene sequences present only in the genome-length RNA of gill-associated virus (GAV). GAV was chosen as a model system firstly due to its availability, and secondly as it is a nidovirus closely related to YHV (Cowley et al. 1999, 2000a, Sittidilokratna et al. 2002), which is capable of causing disease and mortalities in eastern Australian P. monodon (Spann et al. 1997, Callinan et al. 2003). GAV dsRNAs were expressed at high levels in bacteria and incorporated into extruded feed pellets. Bioassays undertaken in P. monodon fed on the pellets, in comparison to shrimp injected with the same dsRNAs puri- fied from the bacteria, showed that injection but not the oral delivery route stimulated strong RNAi responses capable of either rapidly killing shrimp in the case of $\beta$-actin or protecting shrimp against mortalities in the case of GAV. Moreover, the efficacy of the RNAi response to GAV provided by the use of several different dsRNAs suggests that such multi-target strategies might have general applicability in enhancing protection of shrimp against other single-stranded (ss)RNA viruses.

\section{MATERIALS AND METHODS}

Shrimp and experimental tank systems. Pleopods of eighth generation $\left(\mathrm{G}_{8}\right)$ domesticated Penaeus monodon shrimp collected from 4 farm ponds (10 shrimp per pond, weighing 2.5 to $5.5 \mathrm{~g}$ and about $170 \mathrm{~d}$ old) were pre-screened for the endemic viruses GAV and Mourilyan virus (MoV) using RT-PCR (Cowley et al. 2000b, 2005). As neither virus was detected in any of the 40 shrimp (data not shown), shrimp from the same ponds were collected by cast-netting $4 \mathrm{~d}$ later for use in the dsRNA delivery bioassays. The shrimp were transported, weighed and stocked by weight into $100 \mathrm{l}$ circular tanks within $2 \mathrm{~h}$ of capture. Tanks were filled to $80 \mathrm{l}$ with seawater (34 ppt salinity) that was aerated, maintained at $28 \pm 2^{\circ} \mathrm{C}$ and trickle-fed fresh seawater at a rate of $\sim 0.61 \mathrm{~min}^{-1}$. The tanks had opaque white lids and were maintained in a facility providing alternating $12 \mathrm{~h}$ light: $12 \mathrm{~h}$ dark photoperiods. Each tank was stocked with a total of 10 shrimp weighing 2.5-3.0 $\mathrm{g}(\mathrm{n}=1), 3.0-3.5 \mathrm{~g}(\mathrm{n}=2), 3.5-4.0 \mathrm{~g}$ $(\mathrm{n}=3), 4.0-4.5 \mathrm{~g}(\mathrm{n}=3)$, and 5.0-5.5 $\mathrm{g}(\mathrm{n}=1)$.

Replicates for each bioassay group were assigned randomly to 3 tanks to accommodate any positionrelated influences in the facility. Shrimp were fed on extruded pellets manufactured to contain formalinfixed bacteria expressing various dsRNAs as described below. Feed was provided ad libitum twice each day at approximately 09:30 and 17:00 $\mathrm{h}$, and waste was siphoned out 3 times per week or as required to maintain water quality.

GAV inoculum preparation. A GAV inoculum was prepared from Penaeus monodon sacrificed when they became moribund following experimental injection of an inoculum stock prepared similarly from $P$. monodon with high-level acute GAV infections. Soft cephalothorax tissues of 4 shrimp were diluted in 6 volumes shrimp saline solution (SSS) $(10 \mathrm{mM}$ HEPES, $450 \mathrm{mM} \mathrm{NaCl}, 10 \mathrm{mM}$ $\mathrm{KCl}, 10 \mathrm{mM}$ EDTA pH 7.2 to 7.5) that had been $0.22 \mu \mathrm{m}$ filter sterilized and homogenized on ice using an UltraTurrax blender until no granular matter was visible. Fine particulate matter in the homogenate was removed by centrifugation at $750 \times g$ for $10 \mathrm{~min}$ at $4^{\circ} \mathrm{C}$ and then at 
$40000 \times g$ for $20 \mathrm{~min}$ at $4^{\circ} \mathrm{C}$ using a Beckman SW28 rotor. The supernatant was forced through a $0.45 \mu \mathrm{m}$ filter, and $1.0 \mathrm{ml}$ aliquots of the inoculum were snap frozen on dry ice and stored at $-80^{\circ} \mathrm{C}$.

Bioassays to define a minimum lethal dose of GAV inoculum. Three bioassays were performed independently to define a minimum lethal dose (LD) of GAV inoculum that would reliably result in $\sim 50 \%$ accumulated mortality of juvenile Penaeus monodon by Day 8 postinjection (p.i.) and $80 \%$ accumulated mortality by Day 12 p.i. Bioassay LD1 tested the inoculum undiluted and diluted 1:1.5, 1:2, 1:2.5 and 1:3 in SSS. Bioassay LD2 tested the inoculum undiluted and diluted 1:3, 1:4 and 1:5 in SSS. Bioassay LD3 tested the inoculum undiluted and diluted 1:5, 1:10 and 1:20 in SSS. In each bioassay, each inoculum dilution was tested in 3 replicate groups of 10 shrimp. Inoculum was injected into muscle of the 3rd abdominal segment at a dose of $\sim 5.0 \mu \mathrm{l} \mathrm{g}^{-1}$ shrimp weight (i.e. $15.0 \mu \mathrm{l}$ per $3-3.5 \mathrm{~g}, 17.5 \mu \mathrm{l}$ per $3.5-4 \mathrm{~g}$ and $20 \mu \mathrm{l}$ per 4-4.5 g shrimp weight) using a $100 \mu \mathrm{l}$ Hamilton glass syringe fitted with a 26-gauge needle. Shrimp survival was recorded twice daily, at which times any dead shrimp were removed. The bioassays to determine the GAV inoculum LD were terminated on Day 14 p.i. Data obtained from the 3 bioassays identified that the GAV inoculum diluted 1:3 provided the minimum LD reliably generating the accumulated mortality levels specified (data not shown).

Plasmid construction and dsRNA expression in bacteria. Regions of the GAV ssRNA genome were amplified by RT-PCR and cloned into either pGEM-T or pGEM-T Easy vectors (Promega) using standard methods. Portions of Penaeus monodon $\beta$-actin mRNA and fire-fly luciferase mRNA were amplified and similarly cloned into pGEM-T. Sequences of the PCR primers used and the nature of the GAV, $\beta$-actin and luciferase sequences that were amplified and cloned are summarized in Table 1. All PCR products were cloned into pGEM-T except dsGAV-1 and dsGAV-2, which were cloned into pGEM-T Easy. Inserts excised using either NotI (pGEM-T) or EagI (pGEM-T Easy) were subcloned into the same restriction enzyme sites in the dual-T7 promoter plasmid pL4440 (AddGene). Insert fidelity was confirmed by sequence analysis in both directions using the BigDye ${ }^{\circledR}$ Terminator v3.1 Cycle Sequencing Kit (Applied Biosystems) recommended method and sample analysis in an ABI 3130xl Genetic Analyzer (Applied Biosystems).

To express dsRNA in bacteria for purification as described below, single colonies of each pL4440 construct transformed into E. coli HT115(DE3) host cells were selected and seeded into a $10 \mathrm{ml}$ starter culture of lysogeny broth (LB) medium containing $100 \mu \mathrm{g} \mathrm{ml}^{-1}$ ampicillin and $12.5 \mu \mathrm{g} \mathrm{ml}^{-1}$ tetracycline and agitated overnight at $37^{\circ} \mathrm{C}$ in a $50 \mathrm{ml}$ conical flask. A portion (1 to $2 \mathrm{ml}$ ) of each starter culture was used to inoculate a 50 to $100 \mathrm{ml}$ culture agitated at $37^{\circ} \mathrm{C}$ for 2 to $3 \mathrm{~h}$ until the optical density $(\mathrm{OD})_{600 \mathrm{~nm}}$ reached 0.4 to 0.5 . Isopropyl- $\beta$-D-thiogalactopyranoside (IPTG) was then added to a 0.5 to $1.0 \mathrm{mM}$ final concentration to initiate $(+)$ and (-) sense RNA transcription from the opposing T7 promoters in pL4440. The cultures were agitated at $37^{\circ} \mathrm{C}$ for approximately $4 \mathrm{~h}$ until the $\mathrm{OD}_{600 \mathrm{~nm}}$ reached $\sim 1$, at which time the bacteria were harvested.

To express dsRNA in bacteria for incorporation into shrimp feed pellets, essentially the same procedure was

Table 1. PCR primers used to amplify gill-associated virus (GAV), fire-fly luciferase and Penaeus monodon $\beta$-actin sequences cloned into pGEM-T or pGEM-T Easy vectors (Promega) and then sub-cloned into pL4440 (AddGene) to express dsRNA in bacteria. ds: double-stranded; F: forward; R: reverse; ORF: open reading frame; 3CLpro: coronavirus main proteinase; RdRp: RNA-dependent RNA polymerase

\begin{tabular}{|c|c|c|c|c|}
\hline $\begin{array}{l}\text { dsRNA } \\
\text { construct }\end{array}$ & Sequence $\left(5^{\prime}-3^{\prime}\right)$ & $\begin{array}{l}\text { Genome } \\
\text { position }\end{array}$ & $\begin{array}{l}\text { Length } \\
\text { (bp) }\end{array}$ & Motif \\
\hline dsGAV-1 & $\begin{array}{l}\text { F: ACG TTA CGT TCC ACG TAC TTA TC } \\
\text { R: ATC ACG ATT GTA GGT GGA ATC AC }\end{array}$ & $1-907$ & 907 & $\begin{array}{c}\text { ORF1a } \\
5^{\prime} \text {-genome terminus }\end{array}$ \\
\hline dsGAV-2 & $\begin{array}{l}\text { F: ATG ATC AAC CTC CAG AGC TTA GT } \\
\text { R: GAC TAC ATG CCA GTG GTT AAT GT }\end{array}$ & $624-1468$ & 845 & $\begin{array}{c}\text { ORF1a } \\
\text { near 5'-terminus }\end{array}$ \\
\hline dsGAV-3 & $\begin{array}{l}\text { F: AAC GCA TAT GCC CAG GCA ATC GA } \\
\text { R: CCT CTC ACC AGA TTC CGT TGC T }\end{array}$ & $8445-9498$ & 1054 & $\begin{array}{l}\text { ORF1a } \\
\text { 3CLpro region }\end{array}$ \\
\hline dsGAV-4 & $\begin{array}{l}\text { F: GGC GAT GTT GCT GTT GAG CCT } \\
\text { R: ACA CCG GCA TAT CCT GTT CTC TCA CT }\end{array}$ & $13307-13843$ & 537 & $\begin{array}{l}\text { ORF1b } \\
\text { RdRp region }\end{array}$ \\
\hline dsGAV-5 & $\begin{array}{l}\text { F: CAT GCA ATC TGG GAA TCA TCG GCG CA } \\
\text { R: ACC TCA TAC AAA CAC AAC ATC ATC TTC C }\end{array}$ & $17237-18014$ & 778 & $\begin{array}{l}\text { ORF1b } \\
\text { helicase region }\end{array}$ \\
\hline dsLuc & $\begin{array}{l}\text { F: ATG GAA GAC GCC AAA AAC } \\
\text { R: AAC GTG TAC ATC GAC TGA AAT C }\end{array}$ & NA & 500 & $\begin{array}{l}\text { Fire fly luciferase } \\
\text { central mRNA region }\end{array}$ \\
\hline ds $\beta$-actin & $\begin{array}{l}\text { F: TCA CAC AGA TCA TGT TCG AGA } \\
\text { R: CAT TAG GAT AAG GAT TAT GTT ATT }\end{array}$ & NA & 846 & $\begin{array}{l}P . \text { monodon } \beta \text {-actin } \\
3^{\prime} \text {-mRNA region }\end{array}$ \\
\hline
\end{tabular}


followed except that the $10 \mathrm{ml}$ starter culture was used to seed a $500 \mathrm{ml}$ IPTG-induced culture. Bacteria were collected by centrifugation at $6000 \times g$ for $10 \mathrm{~min}$ at $4^{\circ} \mathrm{C}$ in a FIBC-500 rotor, resuspended in $100 \mathrm{ml}$ phosphatebuffered saline (PBS) before being mixed with $100 \mathrm{ml}$ PBS containing $1 \%$ formaldehyde $(0.5 \%$ final concentration) and incubated at room temperature for $15 \mathrm{~min}$ as described by Sarathi et al. (2008). The bacteria were collected by centrifugation, resuspended in $200 \mathrm{ml}$ PBS and centrifuged again. The washed formaldehydefixed bacterial pellet was resuspended in $7 \mathrm{ml}$ PBS, divided into 4 lots equal in volume and pellets collected following micro-centrifugation were frozen at $-80^{\circ} \mathrm{C}$, freeze dried using a Dura-Dry ${ }^{\mathrm{TM}} \mathrm{MP}$ Freeze Drier (TFS Systems) and then stored again at $-80^{\circ} \mathrm{C}$. To ensure the fidelity of dsRNA in bacteria inactivated by mild fixation in $0.5 \%$ formaldehyde, dsRNA was extracted using a phenol:chloroform:isoamyl alcohol method (Sarathi et al. 2008) modified as described below and recovered by preferential precipitation in $4 \mathrm{M} \mathrm{LiCl}$. Integrity of the purified dsRNAs was quantified by a spectrophotometer and gel electrophoresis as described below for dsRNA purified from bacteria. To confirm that the mild formalin-fixation of bacteria did not compromise the RNAi potential of the dsRNA, tail-muscle injection of Penaeus monodon of $\beta$-actin dsRNA extracted from either unfixed or formalin-fixed bacteria was undertaken and found to generate similar mortality rates (data not shown),

dsRNA purification from bacteria. A phenol-chloroform extraction method modified from that described by Sarathi et al. (2008) was used to purify dsRNA from bacteria. Briefly, bacteria from $25 \mathrm{ml}$ aliquots of each IPTG-induced culture were centrifuged at $4000 \times g$ for $15 \mathrm{~min}$ at $4^{\circ} \mathrm{C}$ and each pellet was resuspended in $1.25 \mathrm{ml}$ Tris-ethylenediaminetetraacetic acid (TE) $\mathrm{pH}$ 7.5 and divided equally into two $2 \mathrm{ml}$ tubes. Following vortexing with an equal volume $(\sim 650 \quad \mu l)$ of phenol:chloroform:isoamyl alcohol (25:24:1) and heating at $65^{\circ} \mathrm{C}$ for $10 \mathrm{~min}$, the mixture was micro-centrifuged at $16000 \times g$ for $10 \mathrm{~min}$. The aqueous phase $(\sim 550 \mu \mathrm{l})$ was collected and nucleic acid was precipitated by mixing with 0.2 volumes $4 \mathrm{M} \mathrm{LiCl}$ and an equal volume isopropanol followed by incubation at $-20^{\circ} \mathrm{C}$ for $10 \mathrm{~min}$. Nucleic acid pellets recovered by micro-centrifugation were washed in ice-cold $75 \%$ ethanol, air dried for $10 \mathrm{~min}$ and resuspended in $200 \mu \mathrm{l}$ sterile RNase-free water. To selectively precipitate dsRNA, 1/3 volume $8 \mathrm{M} \mathrm{LiCl} \mathrm{(2} \mathrm{M} \mathrm{final)} \mathrm{was} \mathrm{added,}$ and the mixture was placed at $4^{\circ} \mathrm{C}$ overnight and micro-centrifuged at $16000 \times g$ for $20 \mathrm{~min}$. The dsRNA pellet was washed in ice-cold $75 \%$ ethanol, air dried for $10 \mathrm{~min}$ and resuspended in $50 \mu \mathrm{l}$ water. To remove traces of contaminating tRNA, $1 / 2$ volume $8 \mathrm{M} \mathrm{LiCl}$ (4 $\mathrm{M}$ final) was added and the dsRNA was recovered similarly. To remove traces of contaminating DNA, $6 \mu \mathrm{l}$ $\times 10$ DNase buffer and 4 U DNase 1 (Promega) were added, the mixture incubated at $37^{\circ} \mathrm{C}$ for $30 \mathrm{~min}$ followed by the addition of $200 \mu \mathrm{l}$ TE buffer and phenol:chloroform:isoamyl alcohol exaction as described above. Following addition of 0.1 volumes $3 \mathrm{M}$ sodium acetate $\mathrm{pH} 5.4$ and 1 volume isopropanol, the mixture was incubated at $-20^{\circ} \mathrm{C}$ for $10 \mathrm{~min}$ and dsRNA was pelleted by micro-centrifugation, washed in ice-cold $75 \%$ ethanol, air dried for $10 \mathrm{~min}$ and resuspended in $50 \mu$ l water. A $1.5 \mu$ l aliquot of each purified dsRNA was quantified using a Nanodrop ${ }^{\circledR}$ ND-1000 spectrophotometer (Thermo Scientific), and $800 \mathrm{ng}$ was resolved by electrophoresis in an agarose gel to confirm its size and integrity (Fig. 1). dsRNA was stored at $-80^{\circ} \mathrm{C}$ until used.

Extruded feed manufacture. Feed pellets were manufactured that contained either no bacteria (Diet A) or bacteria expressing each of the 5 GAV dsRNAs (Diet B), luciferase dsRNA (Diet C), $\beta$-actin dsRNA (Diet D) or the short plasmid-derived dsRNA expressed from the host plasmid pL4440 (Diet E). Each diet was prepared fresh on Day 0 of the bioassay and comprised Ridley ${ }^{\circledR}$ AquaFeed mash powder $\left(903 \mathrm{~g} \mathrm{~kg}^{-1}\right)$, Manucol alginate binder $\left(60 \mathrm{~g} \mathrm{~kg}^{-1}\right)$, tetrasodium pyrophosphate (TSPP) (30 $\mathrm{g} \mathrm{kg}^{-1}$ ) and calcium sulphate $\left(4 \mathrm{~g} \mathrm{~kg}^{-1}\right)$. Before weighing, the Ridley ${ }^{\circledR}$ AquaFeed mash was removed from $-20^{\circ} \mathrm{C}$ storage and equilibrated to room temperature. Weighed ingredients were placed in individual mixing bowls for each diet. After removal from $-80^{\circ} \mathrm{C}$ storage and equilibration at room temp, $3 \mathrm{~g} \mathrm{~kg}^{-1}$ freezedried bacteria was ground into the feed powder using a mortar and pestle. In Diet A, an extra $3 \mathrm{~g} \mathrm{~kg}^{-1}$ Ridley ${ }^{\circledR}$

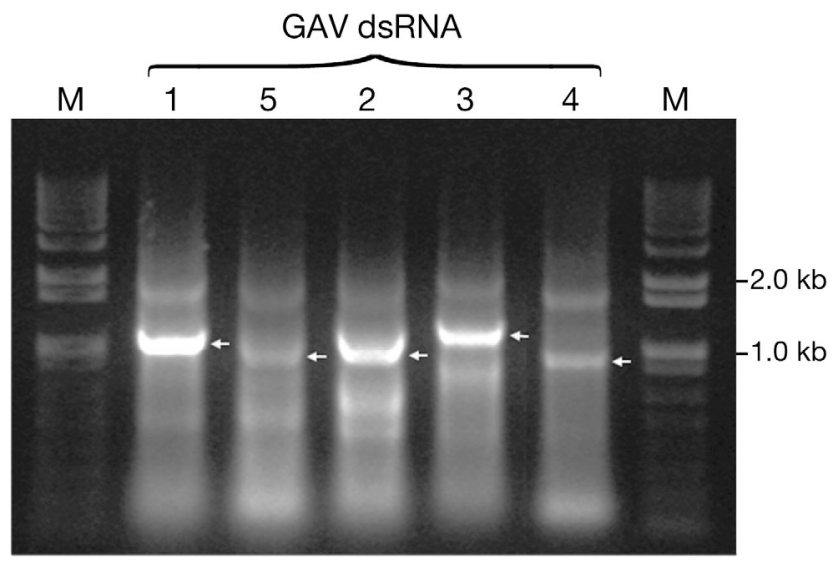

Fig. 1. Agarose gel electrophoresis of 5 gil-associated virus (GAV) double-stranded (ds)RNAs extracted from formalinfixed bacteria to confirm their integrity and size. Prominent bands of about the expected sizes (arrows; see Table 1) were evident for GAV dsRNAs 1, 2, 3, 4 and 5 in addition to some smaller bands and larger faint bands likely representing runoff transcripts from the dual-T7 promoters in pL4440. M: $1 \mathrm{~kb}$ PLUS DNA ladder (Invitrogen) 
AquaFeed mash powder was added instead of bacteria. Each powdered feed mixture was mixed thoroughly using a Kenwood KM800 planetary mixer. Sterile water was then added (28 g per $100 \mathrm{~g}$ ) and mixed in thoroughly to form dough that was extruded through the $2 \mathrm{~mm}$ bore of a syringe. The extruded feed was allowed to set overnight at $4^{\circ} \mathrm{C}$ and broken into pieces 0.5 to $1 \mathrm{~cm}$ in length that were packed in air-tight containers and stored at $-80^{\circ} \mathrm{C}$ until used.

Based on bacterial counts, Diet B contained $4.9 \times 10^{10}$ of the 5 combined GAV-dsRNA bacteria per gram of extruded feed. Bacteria containing each of the $5 \mathrm{GAV}$ dsRNAs were incorporated in equal amounts. Diet C contained $4.8 \times 10^{10}$ luciferase-dsRNA bacteria per gram, Diet D contained $6.0 \times 10^{10} \beta$-actin-dsRNA bacteria per gram and Diet E contained $3.9 \times 10^{10}$ pL4440dsRNA bacteria per gram of feed.

Oral delivery and tail-muscle injection of dsRNA. To deliver dsRNA orally, $\sim 1.0 \mathrm{~g}$ of each diet containing the various formalin-fixed bacteria was fed to each tank of shrimp, initially at 17:00 h on the day the tanks were stocked (Day 0), and then twice daily at 09:30 and 17:00 h over the duration of each bioassay. Each feeding thus provided between $3.9 \times 10^{10}$ and $6.0 \times 10^{10}$ dsRNA-containing bacteria for consumption by the 10 shrimp. To deliver dsRNA by injection, $25 \mu \mathrm{l}$ SSS or SSS containing the various dsRNAs purified from bacteria were injected into muscle of the 3rd abdominal segment between 09:00 and 12:00 h on Day 1 of each bioassay using a $100 \mu \mathrm{l}$ Hamilton glass syringe. Muscle injection was employed to deliver dsRNAs to shrimp as this has previously been demonstrated to result in its systemic distribution to cephalothorax organs such as gills, hepatopancreas, heart and gonads within hours following injection, with some also remaining localized at the vicinity of the delivery site (Robalino et al. 2004, CSIRO unpubl. information). Injection of the same volume irrespective of the weight of the shrimp resulted in the delivery of $15 \mu \mathrm{g}$ pooled GAV dsRNAs (3 $\mu \mathrm{g}$ each of the 5 dsRNAs) or $4 \mu \mathrm{g}$ of either the luciferase or $\beta$-actin dsRNAs per shrimp.

GAV challenge. In GAV challenge bioassays, shrimp were fed on various diets starting on the afternoon of Day 0 or injected with various dsRNAs on the morning of Day 1. Shrimp were injected with the GAV inoculum between 15:00 and 17:00 h on the afternoon of Day 2. Muscle of the 3rd abdominal segment was injected with GAV inoculum diluted 1:3 in SSS ( 5.0 $\mu^{-1} \mathrm{~g}^{-1}$ shrimp weight) using a $100 \mu \mathrm{l}$ Hamilton glass syringe. GAV inoculum volumes adjusted to accommodate variations in shrimp weights were $12.5 \mu \mathrm{l}(2.5-3.0 \mathrm{~g}), 15.0 \mu \mathrm{l}(3-3.5 \mathrm{~g}), 17.5 \mu \mathrm{l}$ (3.5-4 g), $20.0 \mu \mathrm{l}(4-4.5 \mathrm{~g})$ and $22.5 \mu \mathrm{l}(4.5-5.0 \mathrm{~g})$.

Tissue sampling for RNA. On Day 0 of bioassays, pleopods were sampled from 10 spare shrimp from the same experimental cohort using scissors (alcohol steril- ized between samples), snap frozen on dry ice and stored at $-80^{\circ} \mathrm{C}$. On Days 4, 9, 14, 18 and 21, pleopods were sampled similarly from all live shrimp in all bioassays and snap frozen in deep-well 96-well plates embedded in dry ice before being stored at $-80^{\circ} \mathrm{C}$.

Real-time quantitative (q)RT-PCR quantification of RNA. Shrimp pleopods were homogenized in $600 \mu \mathrm{l}$ TRIzol reagent (Invitrogen) using 3 glass beads per tube and a Savant FastPrep FP120 tissue grinder, and total RNA was extracted according to the manufacturer's protocol. RNA was resuspended in $15 \mu$ RNase-free water and before being stored at $-80^{\circ} \mathrm{C}$, a $1.5 \mu$ laliquot was quantified using a NanoDrop-1000 ${ }^{\circledR}$ spectrophotometer to determine the RNA concentration and its relative purity. cDNA was synthesized in a $10 \mu \mathrm{l}$ reaction containing $500 \mathrm{ng}$ total RNA, $50 \mathrm{ng}$ random hexamers and $100 \mathrm{U} \mathrm{Su}-$ perScript $^{\mathrm{TM}}$-III reverse transcriptase (Invitrogen) according to the manufacturer's protocol. A TaqMan real-time qRT-PCR test for GAV was performed as described by de la Vega et al. (2004) except that $2 \mu \mathrm{l}$ cDNA (equivalent to $100 \mathrm{ng}$ total RNA) was used in a $20 \mu \mathrm{l}$ reaction prepared using TaqMan ${ }^{\circledR}$ Universal PCR Master Mix (Applied Biosystems) and $900 \mathrm{nM}$ each PCR primer GAVQPF1 (5'-GGG ATC CTA ACA TCG TCA ACG T-3') and GAVQPR1) 5'-AGT AGT ATG GAT TAC CCT GGT GCA T-3'), from which $3 \times 5 \mu$ aliquots were placed into 3 wells of a 384-well PCR plate as plate replicates. GAV genome regions targeted by the 5 dsRNAs were chosen purposely to not overlap with the region targeted by the qRT-PCR primers (Cowley et al. 2000b, de la Vega et al. 2004), thus ensuring that they could not be co-amplified together with viral genomic RNA in total RNA isolated from injected shrimp.

PCR was performed in an ABI Prism ${ }^{\circledR}$ 9700HT Sequence Detection System (Applied Biosystems) using the default thermal cycling conditions. To quantify GAV RNA copy numbers accurately, cDNA prepared from 10-fold dilutions of synthetic GAV RNA of known copy number was amplified in the same plates to generate linear regression plots of mean cycle threshold $\left(\mathrm{C}_{t}\right)$ values versus synthetic RNA copy number. Adjusting for the presence of cDNA prepared from $25 \mathrm{ng}$ total RNA in each $5 \mu \mathrm{l}$ reaction aliquot analyzed, infection loads were expressed as $\log _{10}$ GAV RNA copies per ng total RNA.

The PCR primers Pmon b-act-F1 (5'-CGG CAT CCA CGA GAC CAC-3') and Pmon b-act-R1 (5'-GTA CAT GGT GGT GCC TCC G-3') were used to quantify Penaeus monodon $\beta$-actin mRNA and the PCR primers PPIA-F1 (5'-GGC AAC AAA TTC GAG GAC-3') and PPIA-R1 (5'-GGG TTT TGA CGG TGC AGA-3') were used to quantify peptidylprolyl isomerise A (PPIA) mRNA in SYBR-Green real-time RT-PCR tests. Briefly, $2 \mu \mathrm{l}$ cDNA (equivalent to $100 \mathrm{ng}$ total RNA) was used in a $20 \mu$ reaction prepared using SYBR-Green Uni- 
versal PCR Master Mix (Applied Biosystems) and $450 \mathrm{nM}$ each PCR primer, from which $3 \times 5 \mu$ liquots were placed into 3 wells of a 384-well PCR plate as plate replicates. PCR was performed in an ABI Prism ${ }^{\circledR}$ 9700HT Sequence Detection System (Applied Biosystems) using the default thermal cycling conditions.

Normalization of real-time RT-PCR data. Real-time RT-PCR $C_{t}$ values obtained for $\beta$-actin mRNA were normalized against $C_{t}$ values obtained for PPIA mRNA for which gene expression levels have been found to be relatively uniform across tissues of individuals of many species including shrimp (Dang 2008). For each pleopod sample, a delta $C_{t}$ value for $\beta$-actin mRNA was determined by subtracting the PPIA $C_{t}$ value obtained with the same sample. A mean delta $C_{t}$ value $\pm S D$ was then determined for the groups of 12 shrimp examined.

Statistical analysis. Survival of shrimp that were injected with SSS in comparison to SSS containing $\beta$ actin dsRNA or that were fed Diets A or D manufactured as described above were initially analyzed for each bioassay by repeated measures ANOVA (PROC GLM; SAS Institute Software 1999). This analysis method was also used to evaluate survival of GAVchallenged shrimp that had been pre-injected with SSS in comparison to SSS containing GAV dsRNAs or 2 non-specific dsRNAs (see above) or that were fed Diets A, B, C and E. As each repeated measures analysis found a significant interaction between treatments and bioassay time point, the data was re-evaluated at each bioassay time point (i.e. day) by 1-way ANOVA; and where these overall analyses were found significant, differences between individual treatments were identified using the least significance difference test.

Amongst shrimp fed pellets incorporating either no bacteria or bacteria containing $\beta$-actin dsRNA, amounts of $\beta$-actin mRNA relative to PPIA mRNA detected by qRT-PCR in pleopod tissue sampled on bioassay Days 4 and 9 were compared by 1-way ANOVA. Amongst shrimp fed pellets incorporating bacteria containing either GAV dsRNAs or luciferase dsRNA before GAV challenge, and shrimp fed pellets without bacteria and either not challenged or challenged with GAV, amounts of GAV genomic RNA detected by qRT-PCR in pleopods sampled on bioassay Days 0 and 4 were also compared by ANOVA and the differences between treatments were quantified using the least significance difference test (SAS Institute Software 1999). Regression analyses of GAV genome amounts quantified by qRT-PCR in pleopods sampled on bioassay Days 4, 9, 14 and 18 were performed separately for shrimp groups (1) not injected with dsRNA and not challenged, (2) not injected with dsRNA and challenged, and (3) injected with GAV dsRNAs or luciferase dsRNA and challenged (SAS Institute Software 1999). As no correlations were apparent within each bioassay group over the time points, treatments were analyzed by 1-way ANOVA using values pooled from all 4 experimental days. Differences between treatments were subsequently identified using the least significance difference test.

\section{RESULTS}

\section{$\beta$-actin dsRNA injection and oral-delivery bioassays}

Amongst groups of 3 replicate tanks each containing 10 Penaeus monodon $(\mathrm{n}=30)$, all shrimp fed Diet A containing no bacteria and most shrimp (90\%) fed Diet $\mathrm{D}$ containing $\beta$-actin dsRNA-containing bacteria remained alive on Day 21 when the bioassays were terminated (Fig. 2). In contrast, significant deaths occurred between Days 2 and 4 amongst shrimp in the group injected intramuscularly with SSS containing $4 \mu \mathrm{g} \beta$-actin dsRNA purified from bacteria (Fig. 2). Only $3(10 \%)$ of the 30 shrimp injected with $\beta$-actin dsRNA remained alive on Day 4 and all shrimp had died by Day 13. Over the same period, only 1 of the 30 control shrimp injected with SSS alone had died.

\section{$\beta$-actin mRNA levels quantified by real-time RT-PCR}

Amongst groups of shrimp fed Diet A containing no bacteria or Diet D containing bacteria in which $\beta$-actin dsRNA had been expressed, pleopods from 12 shrimp were sampled on Days 0,4, 9, 14, 18 and 21 of the bioassay. However, as most shrimp injected with $\beta$ actin dsRNA had died by Day 4, highlighting their acute sensitivity to RNAi knock-down of this mRNA,

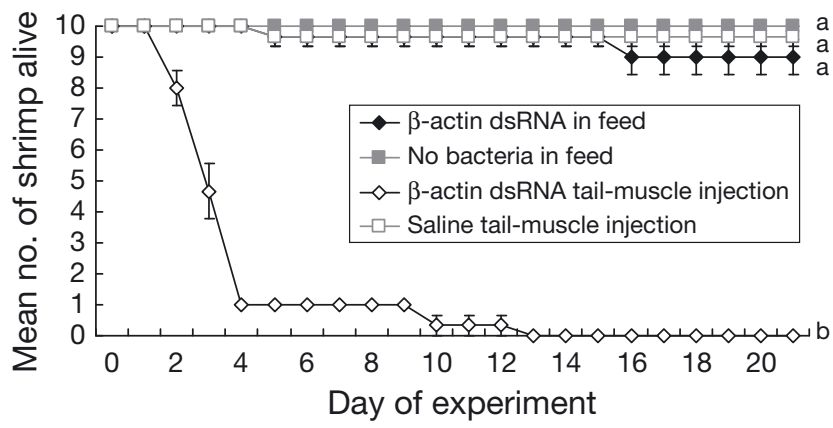

Fig. 2. Penaeus monodon. Mean numbers $( \pm \mathrm{SD})$ of shrimp remaining alive after being fed either pellets containing bacteria expressing high levels of a $P$. monodon $\beta$-actin doublestranded (ds)RNA (Diet D) or pellets containing no bacteria (Diet A), or being injected with the same $\beta$-actin dsRNA purified from bacteria or with saline. At all time points except Days 0 and 1 , mortality numbers in the 3 groups labelled ' $a$ ' were statistically different $(p<0.001)$ from the group labelled 'b' injected with $\beta$-actin dsRNA 
pleopods sampled from shrimp only on Days 4 and 9 of the feeding bioassays were tested by real-time RT-PCR to identify whether any dsRNA delivered within bacteria might have knocked down $\beta$-actin mRNA levels below a threshold needed to cause death. As shown in Fig. 3, no significant differences were identified between the mean delta $C_{t}$ values for $\beta$-actin mRNA, normalized to mean $\mathrm{C}_{\mathrm{t}}$ values obtained in the real-time RT-PCR tests to quantify PPIA mRNA levels, amongst shrimp from either bioassay examined on either day.

\section{GAV dsRNA oral-delivery bioassays}

Amongst groups of 3 replicate tanks each containing 10 Penaeus monodon $(\mathrm{n}=30)$ that were fed on diets containing no bacteria (Diet A) or bacteria expressing each of the 5 GAV dsRNAs (Diet B), luciferase dsRNA (Diet C) or plasmid-derived dsRNA expressed from pL4440 alone (Diet E) from the afternoon of Day 0 and challenged with GAV by muscle injection on the afternoon of Day 2, deaths began to accumulate between Days 5 and 7 in all 4 groups (Fig. 4). By Day 13, shrimp survival had levelled at 15 to $35 \%$ across the 4 groups, after which no more deaths occurred before the bioassays were terminated on Day 21. No mortalities occurred amongst control shrimp not challenged with GAV (Fig. 4). On Day 21 all groups that were challenged with GAV had significantly less living shrimp $(\mathrm{p}<0.001)$, regardless of which diet they were fed, compared to those that were not challenged.

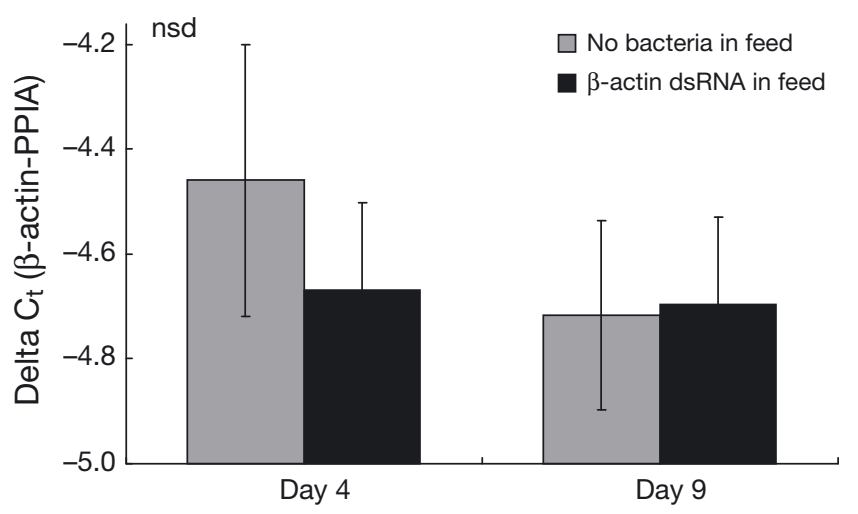

Fig. 3. Delta cycle threshold $\left(C_{t}\right)$ values $( \pm S D)$ obtained by real-time RT-PCR for $\beta$-actin relative to peptidylprolyl isomerise (PPIA) amongst pleopods of 12 Penaeus monodon shrimp selected randomly from groups fed pellets containing either no bacteria (Diet A) or bacteria in which P. monodon $\beta$-actin dsRNA was expressed (Diet D). Data are shown for shrimp sampled on Days 4 and 9 of the bioassay. There was no statistical difference $(n s d)(p>0.005)$ between relative $\beta$-actin mRNA amounts in shrimp sampled from the different treatment groups on either day

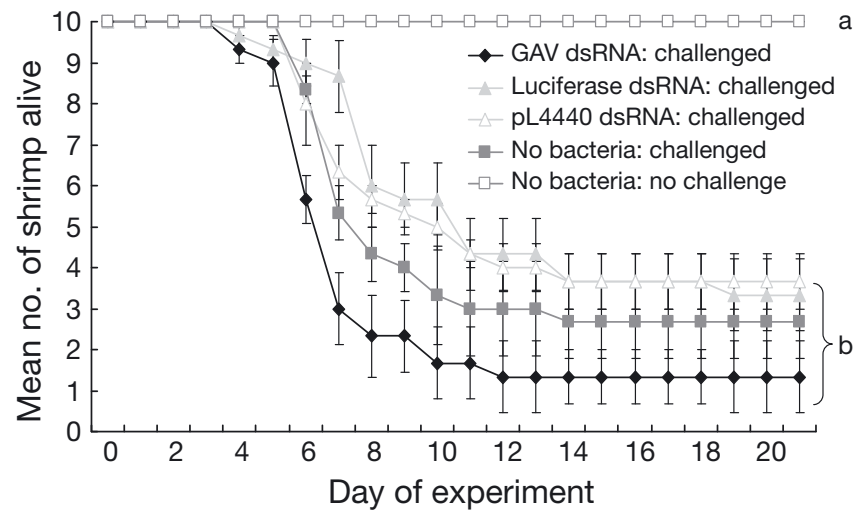

Fig. 4. Penaeus monodon. Feeding bioassays showing mean numbers $( \pm \mathrm{SD})$ of shrimp that remained alive at different times amongst groups challenged with gill-associated virus (GAV) (1:3 inoculum dilution) and fed pellets containing either no bacteria (Diet A) or bacteria in which high levels of GAV (Diet B), luciferase (Diet C) or pL4440 expression vector (Diet E) double-stranded (ds)RNA had been expressed. Significant differences $(p<0.001)$ are indicated by different lowercase letters

\section{GAV dsRNA injection bioassays}

Amongst groups of 3 replicate tanks each containing 10 Penaeus. monodon $(n=30)$ that were pre-injected intramuscularly with SSS, SSS containing luciferase dsRNA or SSS containing the pool of 5 GAV dsRNAs on Day 1 of the bioassays before being challenged with GAV on Day 2, deaths began to accumulate between Days 5 and 7, except in the group pre-injected with the GAV dsRNAs (Fig. 5). By Day 12, shrimp survival had stabilized at $13 \%$ and $10 \%$ in the SSS and SSS luc-

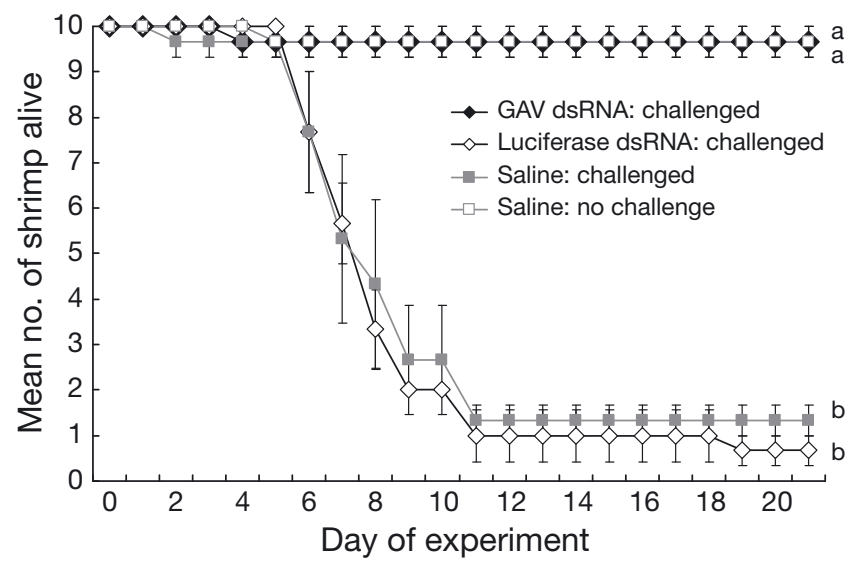

Fig. 5. Penaeus monodon. Injection bioassays showing mean numbers $( \pm \mathrm{SD})$ of shrimp that remained alive at different times amongst groups challenged with gill-associated virus (GAV) (1:3 inoculum dilution) and injected with either saline alone or saline containing either GAV double-stranded (ds)RNA or luciferase dsRNA extracted from bacteria. Significant differences $(p<0.001)$ are indicated by different lowercase letters 
iferase dsRNA pre-injection groups, respectively, with only 1 additional death being recorded before the bioassays were terminated on Day 21. However, amongst shrimp pre-injected with the GAV dsRNAs prior to GAV challenge, survival until Day 19 (97\%) was comparable to the control group not challenged with GAV (Fig. 5). From Day 7 onwards, those groups which received GAV dsRNA and GAV challenge, and those which received SSS and no challenge, had significantly more living shrimp $(p<0.001)$ than all other groups.

\section{GAV RNA loads quantified by real-time qRT-PCR}

Real-time qRT-PCR was used to quantify the impact on GAV replication levels of the various dsRNAs delivered either orally within bacteria or injected into tail muscle. In the oral delivery bioassays, pleopods of 12 shrimp selected randomly from all individuals sampled on Day 0 and after GAV challenge on Day 4 (i.e. Day 2 p.i. with GAV inoculum) were analyzed. As shown in Fig. 6, mean GAV RNA amounts $\left(\log _{10}\right.$ copies per ng total RNA \pm SD) determined for the 12 shrimp fed Diet A containing no bacteria and not challenged with GAV were low on Day 4 (10.0 \pm 2.4) and comparable to mean GAV RNA amounts detected amongst shrimp sampled on Day $0(8.7 \pm 2.9)$. In contrast, mean GAV RNA amounts were in the order of 1000- to 2000-fold higher amongst shrimp sampled after GAV challenge on Day 4, irrespective of whether they had been fed diets containing no bacteria (Diet A; $2.1 \pm 0.9 \times$ $10^{4}$ ) or bacteria expressing either luciferase dsRNA (Diet C; $1.2 \pm 0.5 \times$ $10^{4}$ ) or the pool of 5 GAV dsRNAs (Diet $\mathrm{B}_{i} 1.2 \pm 0.4 \times 10^{3}$ ). In summary, GAV levels were significantly lower $(\mathrm{p}<$ 0.0001) in the 'Day 0' and 'Day 4 no bacteria in feed, no challenge' treatments than in the other 3 treatments.

In the injection bioassays, pleopods of between 3 and 6 shrimp sampled after GAV challenge on Days 4, 9, 14 and 18 were analyzed by real-time qRT-PCR to quantify GAV replication levels. In some bioassays, too few shrimp re- mained alive at later time points to sample 6 individuals. As shown in Fig. 7 , mean GAV RNA amounts $\left(\log _{10}\right.$ copies per ng total RNA) had increased over $10^{4}$-fold by Day 4 amongst shrimp pre-injected with either SSS alone $\left(2.3 \pm 1.1 \times 10^{5}\right)$ or SSS containing luciferase

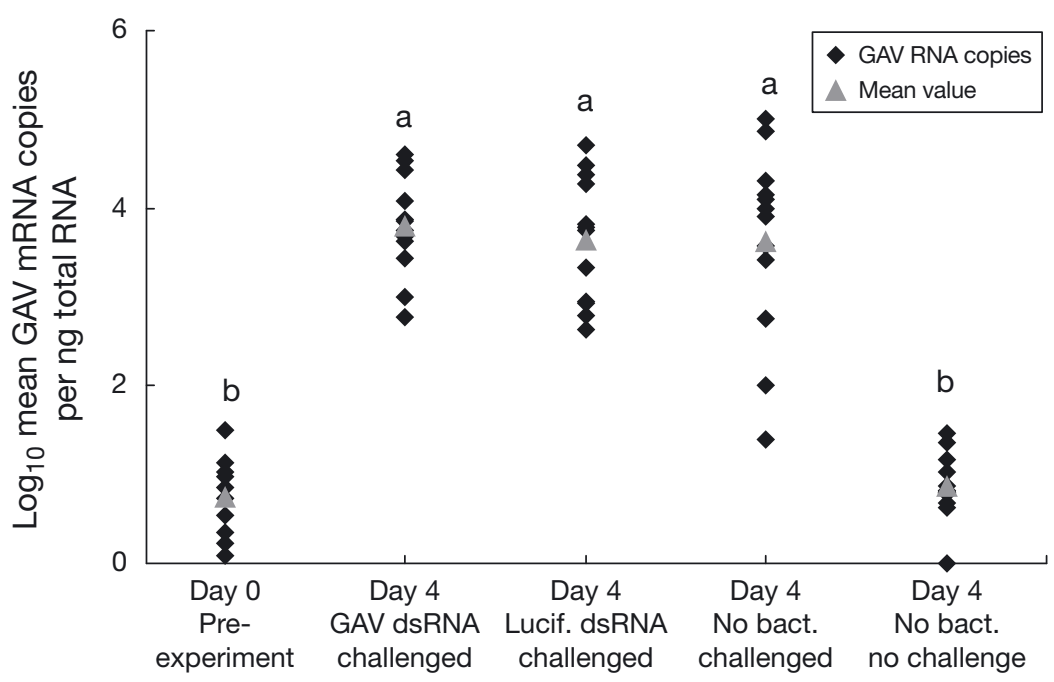

Fig. 6. Real-time RT-PCR quantification of gill-associated virus (GAV) genomic RNA amounts in pleopods of Penaeus monodon sampled on Days 0 and 4 from groups fed pellets containing either GAV double-stranded (ds)RNA (Diet B) or luciferase dsRNA (Diet C) and challenged with GAV, or shrimp fed pellets with no bacteria (Diet A) and either not challenged or challenged with GAV. GAV RNA copies per ng total RNA are shown for each of 12 shrimp selected at random $(\diamond)$ as well as the mean data points $(\Delta)$. Lucif: luciferase; bact.: bacteria. ANOVA and a least significance difference test showed a significant difference $(p<$ 0.005) between GAV RNA levels, as indicated by different lowercase letters

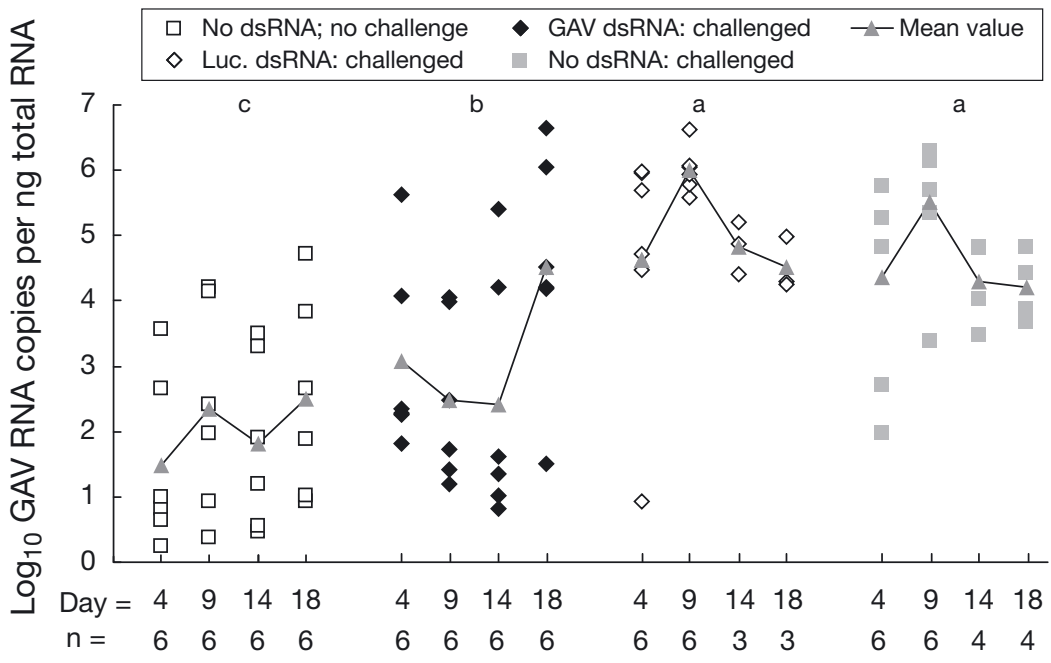

Fig. 7. Real-time RT-PCR quantification of gill-associated virus (GAV) loads in pleopods of Penaeus monodon pre-injected with various double-stranded (ds)RNAs prior to GAV challenge. GAV RNA copies per ng total RNA are shown for each of 3 to 6 shrimp sampled on Days 4, 9, 14 and 18 of the bioassay as well as the mean value determined for the shrimp ( $\Delta)$. Luc.: luciferase. Regression analyses run separately for each treatment revealed no correlations within treatment across time. Treatments with the same lowercase letters are not significantly different when analyzed using values pooled from all 4 experimental days 
dsRNA $\left(4.1 \pm 1.8 \times 10^{5}\right)$ prior to GAV challenge. Mean GAV RNA amounts generally remained elevated in shrimp sampled from these 2 bioassay groups on Days 9,14 and 18, although these dropped slightly in the shrimp sampled on Days 14 and 18. In contrast, mean GAV RNA amounts amongst shrimp pre-injected with the suite of GAV dsRNAs prior to GAV challenge remained low on Days $4\left(7.2 \pm 6.9 \times 10^{4}\right), 9(0.4 \pm 0.2 \times$ $\left.10^{4}\right)$ and $14\left(4.6 \pm 4.3 \times 10^{4}\right)$ and at levels comparable to the non-challenged shrimp injected with SSS alone. On Day 18, however, GAV RNA amounts in 2 of the 6 shrimp sampled $\left(1.1 \times 10^{6}\right.$ and $4.32 \times 10^{6}$ copies per ng total RNA) had increased to levels comparable to shrimp that had the highest GAV infection loads amongst the control groups injected either with SSS alone or SSS containing luciferase dsRNA before challenge with GAV. In summary, 1-way ANOVA indicated a significant difference in GAV loads among treatments when analyzed using values pooled from all 4 experimental days. GAV loads were significantly higher in the 'luciferase dsRNA, GAV challenged' and 'no dsRNA, GAV challenged' treatments than the other 2 treatments. Furthermore, GAV loads were significantly higher in the 'GAV dsRNA, GAV challenged' than in the 'no dsRNA, no GAV challenge' treatment.

\section{DISCUSSION}

The data reported here indicate that antiviral RNAi responses to GAV infection are not readily induced in juvenile Penaeus monodon when dsRNA is delivered orally as a feed component. This approach was trialled primarily as there is immense interest in finding effective commercially applicable means of delivering dsRNA to farmed shrimp as antiviral prophylactics. Secondly, it warranted further investigation as Sarathi et al. (2008) recently reported reductions in WSSV replication and mortalities amongst $P$. monodon challenged by ingestion of muscle tissue from WSSVinfected shrimp at the same time as being fed on feed pellets coated with formalin-fixed bacteria in which dsRNA targeted to the WSSV VP28 gene mRNA had been expressed in abundance.

Despite the encouraging results reported by Sarathi et al. (2008), it was expected that the efficiency with which dsRNA could cross the shrimp gut-wall barrier and be disseminated systemically in circulated haemolymph would to be low. In considering this and to maximize the potential for delivering an RNAi response capable of interfering with GAV replication, dual-T7 expression plasmids were constructed to generate long (537 to $1054 \mathrm{bp}$ ) dsRNAs targeted to 5 regions in the GAV ssRNA genome. By utilizing a pool of dsRNAs targeted to multiple regions in the GAV
ORF1a/1b gene, we hypothesized that RNAi-mediated destruction of the viral genomic RNA might be enhanced, both due to these dsRNA targeting only genomic-length GAV RNA forms and to some genome regions potentially being more susceptible to dsRNAmediated cleavage and destruction. The suite of dsRNAs was selected to include 2 targeted at the $5^{\prime}$-terminus and near $5^{\prime}$-terminus of the GAV genome to preferentially destroy sequence motifs needed for polymerase binding to perpetuate GAV genome replication. Moreover, whilst the genes encoding GAV structural proteins might be seen as reasonable targets to mount anti-viral RNAi responses, as found to be the case with WSSV (Kim et al. 2007, Sarathi et al. 2008) and other shrimp viruses, targeting such genes in okaviruses is expected to be inefficient. This inefficiency stems from such dsRNAs interacting not only with the genomic-length $(+)$ and $(-)$ sense RNAs, but also with either or both of the $2(+)$ sense 3 '-coterminal sub-genomic ssRNAs from which the virion structural proteins are translated, as well as their (-) sense subgenomic ssRNA counterparts, both of which are transcribed in higher abundance than the genomic-length RNAs (Cowley et al. 2002, Sittidilokratna et al. 2008). Indeed, this has been demonstrated with a dsRNA targeted to the ORF3 gene that encodes the gp116 and gp64 structural glycoproteins of the closely related YHV, which was found to be far less effective at inhibiting virus replication, pathology and mortalities compared to dsRNAs targeted to ORF1a/1b gene motifs (Tirasophon et al. 2005, 2007) and thus only the genome-length ssRNAs.

In the oral delivery approach examined here, dsRNA encapsulated within formalin-fixed bacteria prepared as described by Sarathi et al. (2008) and then freeze dried to aid stability was manufactured into feed pellets rather than being coated onto commercial feed pellets (Sarathi et al. 2008). This approach was taken to substantially increase the amounts of bacteria that could be delivered compared to that $\left(\sim 10^{8}\right.$ bacteria per gram) deliverable by surface absorption of bacteria onto dry feed pellets as used in the WSSV bioassays (Sarathi et al. 2008). Indeed, even when freeze-dried bacteria were used at $3 \mathrm{~g} \mathrm{~kg}^{-1}$ dry weight of feed ingredients, estimated bacterial numbers $\left(4\right.$ to $6 \times 10^{10}$ ) per gram of feed were in the order of 400- to 600 -fold higher than that estimated to be coated onto feed. Despite this higher concentration of bacteria in the feed, its palatably was unaffected as demonstrated by Penaeus monodon exhibiting typical eating behaviours in which pellets were grasped immediately when offered and consumed by rolling them in circles to shred the pellet against their mouthparts, either whilst on the tank bottom or swimming (Dall et al. 1990). Moreover, it was envisaged that by manufacturing the 
bacteria into feed pellets, leaching from the pellet surface during hydration might be reduced and bacteria might be protected more effectively against digestive enzymes in the shrimp gut environment, thus promoting opportunities for dsRNA to be released more progressively into varied regions along the digestive tract. However, more detailed investigations of feed uptake by the shrimp digestive tract are needed to determine where dsRNA is released from the bacteria and its fate thereafter.

Despite the use of oral delivery approaches to help maximize the potential for anti-viral RNAi responses to GAV or for lethal RNAi responses to Penaeus monodon $\beta$-actin mRNA, no evidence of effects were observed even though muscle injection of the same dsRNAs purified from the bacteria mounted highly effective RNAi responses in either model system. It is not known to what extents the bacterial fixation and/or feed formulation processes, permeability of the shrimp gutwall barrier, dsRNA degradation by gut digestive nucleases and other possible biological obstacles contributed to the failure of the oral delivery approach to generate RNAi responses. Discounting this failure, however, it is important that such methods continue to be refined and explored, as approaches examined thus far have only offered non-specific or no or low-level specific protection against viral pathogens (Lauth et al. 2010) even though many studies have now proven beyond doubt that virus-specific dsRNAs can be potent antiviral prophylactics when injected into shrimp (Robalino et al. 2005, Tirasophon et al. 2005, 2007, Yodmuang et al. 2006, Saksmerprome et al. 2009). Moreover, there remains great potential for using dsRNA muscle injection as a means, for example, of lessening loads or clearing viral infections from valuable broodstock prior to spawning to break vertical transmission cycles, particularly in regions where viruses such as WSSV continue to be a major impediment to shrimp aquaculture, or of interfering with biological pathways to promote ovary development and spawning in the absence of eye ablation that inevitably results in shrimp death from reproductive exhaustion.

Previous studies of other shrimp viruses have reported varying levels of protection when a dsRNA to a single gene target has been pre-injected into muscle prior to challenge. For example, in an early study examining WSSV replication in Litopenaeus vannamei, Robalino et al. (2005) reported short-term protective levels relative to control shrimp challenged with WSSV that varied for dsRNAs targeted to gene mRNAs encoding RR2 (78\%), VP28 (85\%) and a viral DNA polymerase $(44 \%)$. In comparison, a study of RNAi responses to YHV infection in Penaeus monodon found that pre-injection of a dsRNA targeted to the 3CL-protease motif in the ORF1a gene afforded
$95 \%$ protection against mortalities over a $10 \mathrm{~d}$ period post-challenge (Yodmuang et al. 2006). More recently, a study of RNAi responses to YHV replication in $L$. vannamei found that injection of a dsRNA targeted to the RNA polymerase motif in the ORF1b gene afforded $87 \%$ protection against mortalities over a $14 \mathrm{~d}$ period post-challenge (Saksmerprome et al. 2009). In the bioassays reported here, muscle injection of a pool of 5 GAV dsRNAs interfered strongly with GAV replication in juvenile $P$. monodon injected with a lethal dose of GAV that was selected to reliably generate $\sim 50 \%$ accumulated mortality by 8 d p.i. and $~ 80 \%$ accumulated mortality by $12 \mathrm{~d}$ p.i. Over the $19 \mathrm{~d}$ period following GAV challenge, after which the bioassays were terminated, none of the 30 shrimp injected with the GAV dsRNA cocktail had died in comparison to $96 \%$ of shrimp not pre-injected with any dsRNA and $99 \%$ of shrimp pre-injected with a non-related dsRNA. Moreover, GAV replication levels in most shrimp were found to be maintained at basal levels up until Day 14 of the bioassay and only showed generally higher infection levels on Day 18. No attempt was made to quantify residual dsRNA levels in pleopods sampled from shrimp, and as shrimp could not logistically be tagged or housed individually, it was not possible to correlate this to GAV loads in individuals as infections progressed over time. However, from this and other studies, it is clear that factors including dsRNA amounts and the nature and number of dsRNAs used can all greatly affect the protective efficacy of RNAi against virus-induced disease. Moreover, whilst the combined administration of 5 GAV dsRNAs targeted to differing regions in the ORF1a/1b gene, and thus only the genomic-length RNA (Cowley et al. 2000a, 2002), provided extended protection against disease and mortalities, additional studies are needed to quantify what improvements in efficacy this approach offers over the administration of fewer or single dsRNAs.

To confirm that the dsRNA oral-delivery approach examined here using a model GAV bioassay system was incapable of elucidating an effective RNAi response, bioassays were also undertaken using $\beta$-actin mRNA as an endogenous target for dsRNA capable of rapidly causing shrimp death (M. J. Sellars et al. unpubl.). As found previously, juvenile Penaeus monodon were killed rapidly following muscle injection of $\beta$-actin dsRNA. In contrast and similarly to the GAV challenge bioassays, shrimp survival was not compromised when the same dsRNA was delivered orally within bacteria incorporated into feed pellets. Moreover, in bioassays not described here using commercial feed pellets soaked in $\beta$-actin dsRNA-containing bacteria and then glazed in egg white, as used to demonstrate limited protection against WSSV (Sarathi 
et al. 2008), no mortalities occurred and $\beta$-actin mRNA levels were unaffected as determined using real-time RT-PCR (M. J. Sellars et al. unpubl.). Furthermore, a muscle injection experiment was performed to confirm that $\beta$-actin dsRNA extracted from formalin-fixed bacteria retained its ability to kill shrimp as effectively as dsRNA isolated from non-fixed bacteria, thus demonstrating that the mild fixation used to inactivate the bacteria did not compromise dsRNA functionality (M. J. Sellars et al. unpubl.).

In summary, therefore, the data reported here confirm that dsRNA muscle injection can mount very effective RNAi responses in Penaeus monodon to both endogenous mRNA species as well as exogenous viral RNAs, thereby affording protection against disease, but indicates that such responses are not easily delivered by the oral route using dsRNA encapsulated within formalin-inactivated bacteria incorporated into feed. Despite the failure of these preliminary attempts to deliver anti-GAV RNAi responses to shrimp via the oral route, further investigations of alternative methods with potential for commercial application are warranted due to the substantial economic gains that could be derived from protecting farmed shrimp against devastating viral diseases.

Acknowledgements. The authors thank D. Underwood, C. Murray, E. Nowak, D. Blyth and M. Anderson for assistance with shrimp injections, sampling and husbandry, S. Tabrett for assistance with diet formulations and G. Coman for assistance with statistical analysis.

\section{LITERATURE CITED}

Assavalapsakul W, Smith DR, Panyim S (2006) Identification and characterization of a Penaeus monodon lymphoid cell-expressed receptor for the yellow head virus. J Virol 80:262-269

Callinan RB, Jiang L, Smith PT, Soowannayan C (2003) Fatal, virus-associated peripheral neuropathy and retinopathy in farmed Penaeus monodon in eastern Australia. I. Pathology. Dis Aquat Org 53:181-193

Cowley JA, Dimmock CM, Wongteerasupaya C, Boonsaeng V, Panyim S, Walker PJ (1999) Yellow head virus from Thailand and gill-associated virus from Australia are closely related but distinct prawn viruses. Dis Aquat Org 36:153-157

> Cowley JA, Dimmock CM, Spann KM, Walker PJ (2000a) Gill-associated virus of Penaeus monodon prawns: an invertebrate virus with ORF1a and ORF1b genes related to arteri- and coronaviruses. J Gen Virol 81:1473-1484

Cowley JA, Dimmock CM, Spann KM, Walker PJ (2000b) Detection of Australian gill-associated virus (GAV) and lymphoid organ virus (LOV) of Penaeus monodon by RTnested PCR. Dis Aquat Org 39:159-167

Cowley JA, Dimmock CM, Walker PJ (2002) Gill-associated nidovirus of Penaeus monodon prawns transcribes 3 '-coterminal subgenomic mRNAs that do not possess 5'-leader sequences. J Gen Virol 83:929-937
Cowley JA, McCulloch RJ, Rajendran KV, Cadogan LC, Spann KM, Walker PJ (2005) RT-nested PCR detection of Mourilyan virus in Australian Penaeus monodon and its tissue distribution in healthy and moribund prawns. Dis Aquat Org 66:91-104

Dall W, Hill BJ, Rothlisberg PC, Staples DJ (1990) The biology of the Penaeidae. In: Blaxter JHS, Southward AJ (eds) Advances in marine biology, Vol 27. Academic Press, New York, NY, p 323-328

Dang OTH (2008) Inhibition of viral infection in Penaeus monodon prawns by using RNA interference. $\mathrm{PhD}$ thesis, University of Queensland, Brisbane

de la Vega E, Degnan BM, Hall MR, Cowley JA, Wilson KJ (2004) Quantitative real-time RT-PCR demonstrates that handling stress can lead to rapid increases of gill-associated virus (GAV) infection levels in Penaeus monodon. Dis Aquat Org 59:195-203

Dechklar M, Udomkit A, Panyim S (2008) Characterization of Argonaute cDNA from Penaeus monodon and implication of its role in RNA interference. Biochem Biophys Res Commun 367:768-774

Kim CS, Kosuke Z, Nam YK, Kim SK, Kim KH (2007) Protection of shrimp (Penaeus chinensis) against white spot syndrome virus (WSSV) challenge by double-stranded RNA. Fish Shellfish Immunol 23:242-246

Lauth X, Stannard J, Tran T, Coger K, Fujimoto A, Buchanan J (2010) Toward oral delivery of an RNAi based antiviral therapeutic for shrimp aquaculture. Proc World Aquaculture Soc Conf, March 1-5, San Diego, CA, p 562

> Lugo JM, Morera Y, Rodriguez T, Huberman A, Ramos L, Estrada MP (2006) Molecular cloning and characterization of the crustacean hyperglycemic hormone cDNA from Litopenaeus schmitti. Functional analysis by doublestranded RNA interference technique. FEBS J 273: 5669-5677

> Maningas MB, Kondo H, Hirono I, Saito-Taki T, Aoki T (2008) Essential function of transglutaminase and clotting protein in shrimp immunity. Mol Immunol 45:1269-1275

Robalino J, Browdy CL, Prior S, Metz A, Parnell P, Gros P, Warr G (2004) Induction of antiviral immunity by double-stranded RNA in a marine invertebrate. J Virol 78:10442-10448

Robalino J, Bartlett T, Shepard E, Prior S and others (2005) Double-stranded RNA induces sequence specific antiviral silencing in addition to nonspecific immunity in a marine shrimp: convergence of RNA interference and innate immunity in the invertebrate antiviral response. J Virol 79: 13561-13571

Robalino J, Bartlett T, Chapman RW, Gross P, Browdy CL, Warr GW (2007) Double-stranded RNA and antiviral immunity in marine shrimp: inducible host mechanisms and evidence for the evolution of viral counter-responses. Dev Comp Immunol 31:539-547

Saksmerprome V, Charoonnart P, Gangnonngiw W, Withyachamnarnkul B (2009) A novel and inexpensive application of RNAi technology to protect shrimp from viral disease. J Virol Methods 162:213-217

Sarathi M, Simon MC, Venkatesan C, Sahul-Hameed AS (2008) Oral administration of bacterially expressed VP28dsRNA to protect Penaeus monodon from white spot syndrome virus. Mar Biotechnol 10:242-249

SAS Institute Software (1999) SAS/STAT software, version 7. SAS Institute, Cary, NC

Sellars MJ (2007) Mechanisms that control Kuruma shrimp gender and fertility. PhD thesis, University of Queensland, Brisbane

> Sittidilokratna N, Hodgson RAJ, Cowley JA, Jitrapakdee S, Boonsaeng V, Panyim S, Walker PJ (2002) Complete 
ORF1b-gene sequence indicates yellow head virus is an invertebrate nidovirus. Dis Aquat Org 50:87-93

Sittidilokratna N, Dangtip S, Cowley JA, Walker PJ (2008) RNA transcription analysis and completion of the genome sequence of yellow head nidovirus. Virus Res 136:157-165

Spann KM, Cowley JA, Walker PJ, Lester RJG (1997) A yellow-head-like virus from Penaeus monodon cultured in Australia. Dis Aquat Org 31:169-179

Su J, Oanh DT, Lyons RE, Leeton L and others (2008) A key gene of the RNA interference pathway in the black tiger shrimp, Penaeus monodon: identification and functional characterisation of Dicer-1. Fish Shellfish Immunol 24: 223-233

Tirasophon W, Roshorm Y, Panyim S (2005) Silencing of yellow head virus replication in penaeid shrimp cells by dsRNA. Biochem Biophys Res Commun 334:102-107

Tirasophon W, Yodmuang S, Chinnirunvong W, Plongthongkum N, Panyim S (2007) Therapeutic inhibition of yellow head virus multiplication in infected shrimps by YHVprotease dsRNA. Antiviral Res 74:150-155

Tiu SHK, Chan S (2007) The use of recombinant protein and RNA interference approaches to study the reproductive functions of a gonad-stimulating hormone from the shrimp Metapenaeus ensis. FEBS J 274:4385-4395

Editorial responsibility: Grant Stentiford, Weymouth, UK
Tiu SHK, Benzie J, Chan S (2008) From hepatopancreas to ovary: molecular characterisation of a shrimp vitellogenin receptor involved in the processing of vitellogenin. Biol Reprod 79:66-74

Treerattrakool S, Panyim S, Chan SM, Withyachumnarnkul B, Udomkit A (2008) Molecular characterization of gonadinhibiting hormone of Penaeus monodon and elucidation of its inhibitory role in vitellogenin expression by RNA interference. FEBS J 275:970-980

Unajak S, Boonsaeng V, Jitrapakdee S (2006) Isolation and characterization of cDNA encoding Argonaute, a component of RNA silencing in shrimp (Penaeus monodon). Comp Biochem Physiol 145:179-187

Westenberg M, Heinhuis B, Zuidema D, Vlak J (2005) siRNA injection induces sequence-independent protection in Penaeus monodon against white spot syndrome virus. Virus Res 114:133-139

> Xu J, Han F, Zhang X (2007) Silencing shrimp white spot syndrome virus (WSSV) genes by siRNA. Antiviral Res 73: 126-131

Yodmuang S, Tirasophon W, Roshorm Y, Chinnirunvong W, Panyim S (2006) YHV-protease dsRNA inhibits YHV replication in Penaeus monodon and prevents mortality. Biochem Biophys Res Commun 341:351-356

Submitted: October 11, 2011; Accepted: February 2, 2011 Proofs received from author(s): May 11, 2011 